[豊化 第 45 巻、第 4 号, p. $169 \sim 175,1971$ ]

\title{
Portulol の化学的性質と生理活性について
}

\author{
安部八洲男*, 谷口栄二, 江藤守総, 大岛承義** \\ (九洲大学農学部愄筀化学科)
}

昭和 45 年 9 月 14 月受理

Some Chemical Properties and Biological Activity of Portulol

By Yasuo ABE, * Eiji TAniguchl, Morifusa ETo and Yasuyoshi OshmMA**

Department of Agricultural Chemistry, Faculty of Agriculture, Kyushu University

Portulal (I), a plant growth regulator from Portulaca grandiflora Hook., was oxidized with active manganese dioxide to give a $\gamma$-lactone (II). The aldehyde group of $I$ was reduced with lithium aluminium hydride to yield portulol (III). III was converted to an $\alpha, \beta$-unsaturated aldehyde (IV) through dehydration, rearrangement and cyclization by treatment with hydrochloric acid solution.

Both I and III inhibited the IAA-induced lamina joint elongation of rice plants. However, III did not show any effect on the GA-induced formation of $\alpha$-amylase in isolated barley endosperms, but I showed an inhibitory effect.

Present address:*Research Department, Pesticide Division, Sumitomo Chemical Co., Osaka; **Faculty of Agriculture, Meiji University, Kawasaki

(Received September 14, 1970)

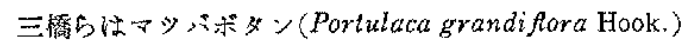

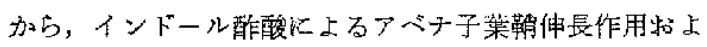

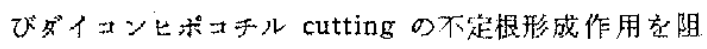
書し(1)，他方ア゙ズ和と゚ュチル cutting の不定根形成 作用を促谁する(2)物繁を単離した(1). Yamazaki ち(3)

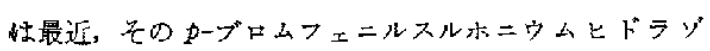

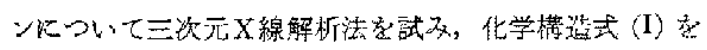
提出してこれをPortulal と命名した。

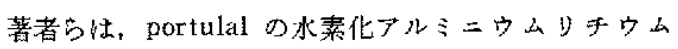

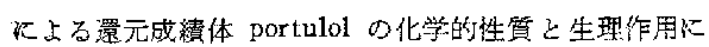

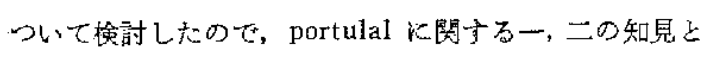

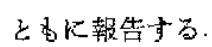

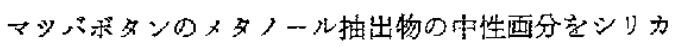

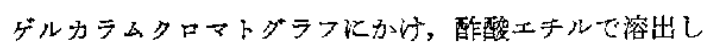
て得られる粗結晶を希王タノールから再結晶を行ない, 無色針状昆索得た。この標品住䗝点が $117.0 \sim 117.5^{\circ} \mathrm{C}$

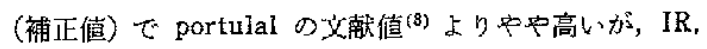
NMR (Fig. 1)，UV招上び泿融試駼尗り Yamazaki b

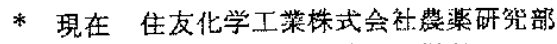

** 現在 明治大学费学部费芸化学科

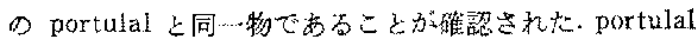
とその2,4-ジニトロフェニルヒドシゾン(V)のスペ

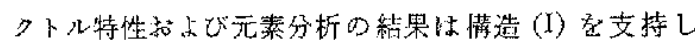
た***.

Portulal 去活性一酸化マンガンで酸化すると, 油状物

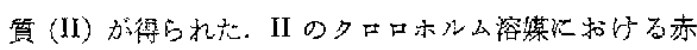

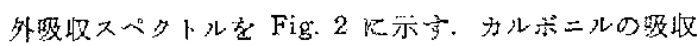

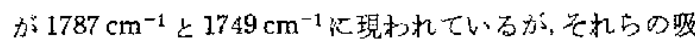

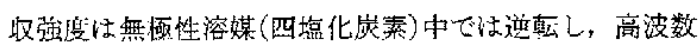
側のうが強くなった。これは

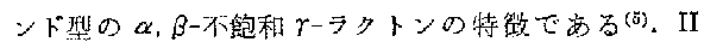

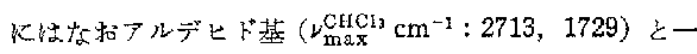
級アルンール $\left(\nu_{\max }^{\mathrm{CHCl} 3} \mathrm{~cm}^{-1}: 3645,1037\right)$ 方牫存してい る.これらのことから，二酸化マンガンにより portulal の 15 位の一級アルコールがアルデヒド酸化され ${ }^{(6)}$,

\footnotetext{
*** 分子荲について：マススペクトルで分子イホンピ 一クが検出されず，理猃值 336 上り大きいピークす

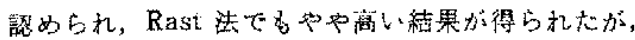

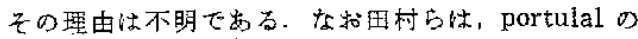
X線解析火上り分子量 326.5 (證美 $3 \%$ ) 得てい $z^{(4)}$.
} 


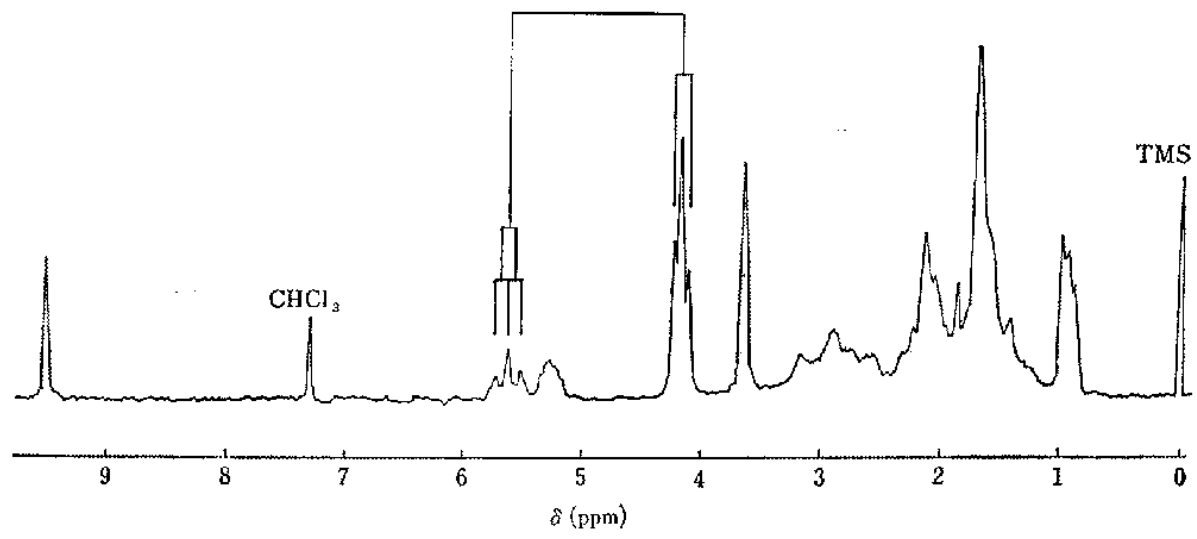

Fig. 1. NMR Spectrum of Poltulal (I) at $60 \mathrm{Mc}$ in $\mathrm{CDCl}_{3}$.

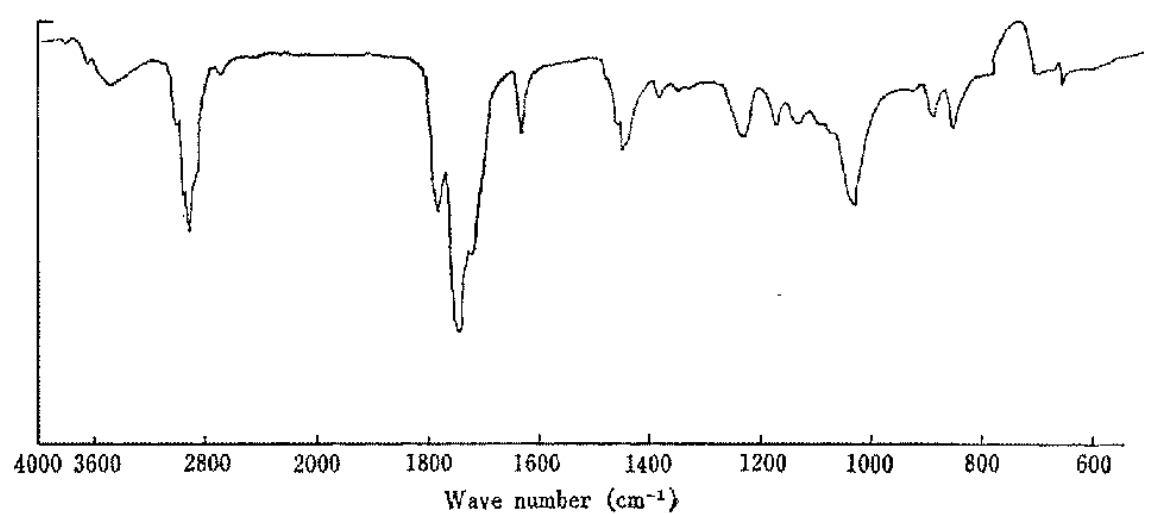

Fig. 2. IR Spectrum of $r$-Lactone (II) in $\mathrm{CHCl}_{3}$.

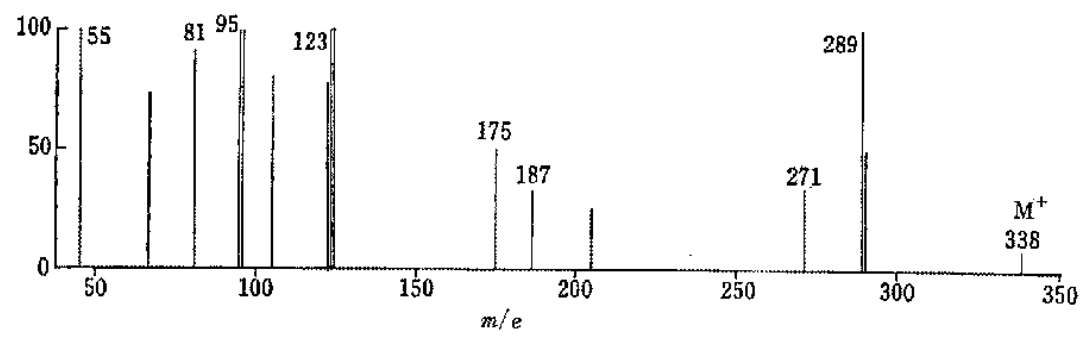

Fig. 3. Mass Spectrum of Portulol (III).

16 位のアルュールとへミアせタール構造をとって閉環

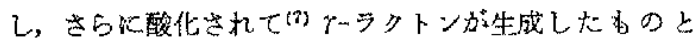
推察される.

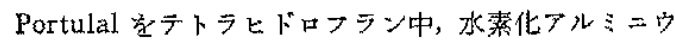
ムリチウムにより還元すると、ジとドロ体 $\mathrm{C}_{24} \mathrm{H}_{34} \mathrm{O}_{4}(\mathrm{III})$ の無色粉末 $\mathrm{mp} 40 \sim 42^{\circ} \mathrm{C}$ 方得占れた。 これを portulol と称守ること伢す。 portulol は portulal と異なり， マススペクトルで明傹に分子イオン $m / e 338$ が㒛めら れた (Fig. 3). portulol のスペクトル特性は portulal
のそれと此䡜し，それぞれ帰属することができるが，後 者で楒められたアルデヒド基の汲收 $\left(\nu_{\max }^{\mathrm{KBr}} 1722 \mathrm{~cm}^{-1}\right.$,

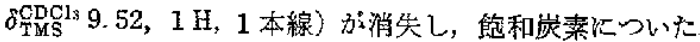

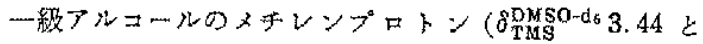
3.30，4H）肪 $2 \mathrm{H}$ だ什增加していることから, portulal

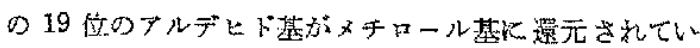

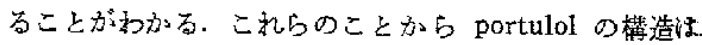
III て示豆光。

Portulol(III)を $1.5 \%$ 塩酸一メタノール溶液中で這流す 


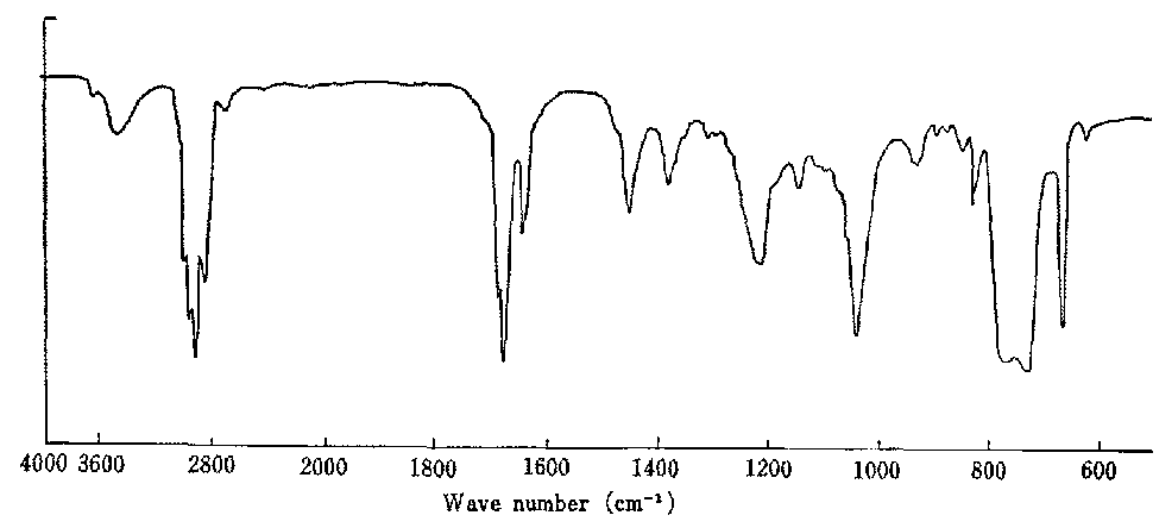

Fig. 4. IR Spectrum of Carbonyl Compound (IV) in $\mathrm{CHCl}_{3}$.

るとカルボニル化合物(IV)の祭色立方晶， $\mathrm{mp} 113 \sim 114^{\circ} \mathrm{C}$ が得られた. マススペクルル m/e $320\left(\mathrm{M}^{+}\right)$, 坆よび元 菜分析圷より分子武 $\mathrm{C}_{20} \mathrm{H}_{32} \mathrm{O}_{3}$ が得ら机た. IV の UV $\lambda_{\max }^{\mathrm{EtOR}} \mathrm{m} \mu(\varepsilon): 230(30,500), 273(3900)$ 怙よび IR (Fig.

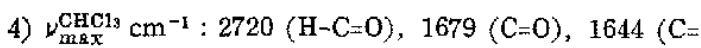
C) は $\alpha, \beta$-不竘和アルデヒドの存在を示唆している. こ和は以下㳀べる5に2,4-ジニトロフェニルヒト ラソンの吸收スペタトルのアルカリに対する挙動や NMR Kよっても支持された。

IV 2,4-ジニトロフェニルレドラソ゚ソ(VI) $\mathrm{C}_{26} \mathrm{H}_{96}$ $\mathrm{O}_{6} \mathrm{~N}_{4}$, MS m/e $500\left(\mathrm{M}^{+}\right)$は UV $\lambda_{\mathrm{max}}^{\mathrm{CHCla}} \mathrm{m} \mu(\varepsilon): 258$

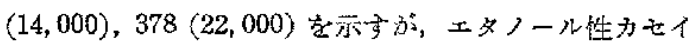

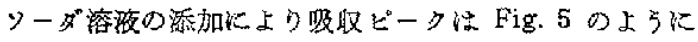
450 扎うび $550 \mathrm{~m} \mu$ に深色移動孛起こし, 時間の経過と

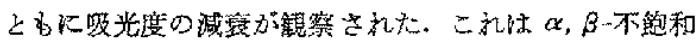
アルデレドの特微である(日).

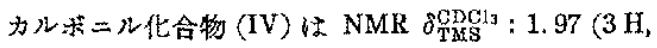
2 重線， $\left.J=7.1 \mathrm{cps}, \quad \mathrm{CH}_{\mathrm{g}}-\mathrm{C}=\mathrm{C}-\mathrm{C}=0\right), 6.60(1 \mathrm{H}, 4$ 重 線, $J=7.1 \mathrm{cps}, \mathrm{H}-\mathrm{C}=\mathrm{C}-\mathrm{C}=0), 9.43(1 \mathrm{H}, 1$ 本線, $\mathrm{H}-$ C=0) のシグナルを示す (Fig. 6). portulal, portulol

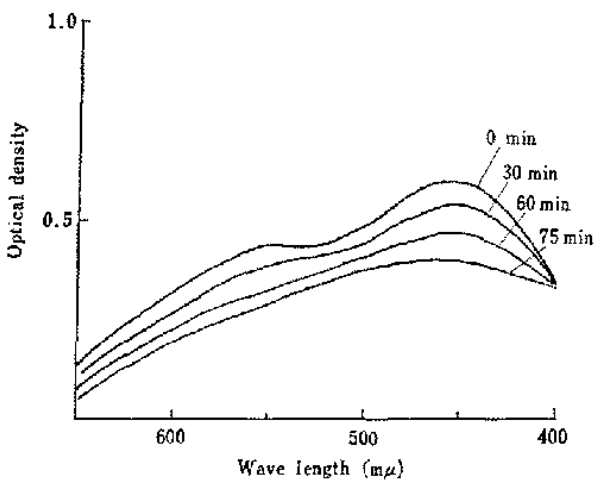

Fig. 5. Decrease in Absorption Intensity of VI by Addition of $0.25 \mathrm{~N} \mathrm{NaOH}-\mathrm{EtOH}$.

と黑なりオレフィン性ブロトン忧たた1個のみて，か $2 ， \alpha ， \beta$-不飽和メチル基とスピンースピン相互作用を示 している.したがって部分構造 $\mathrm{CH}_{3}-\mathrm{CH}=\underset{\mathrm{R}}{\mathrm{C}}-\mathrm{CH}=\mathrm{O}$ 方推 定される。このような部分端造仙 portulal や portulol にはなく、一方々れらで政 $\delta 4$ 付近に認められた $\alpha, \beta-$

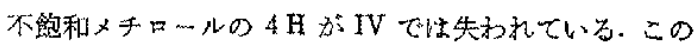
こと注 portulol $の$ butenediol

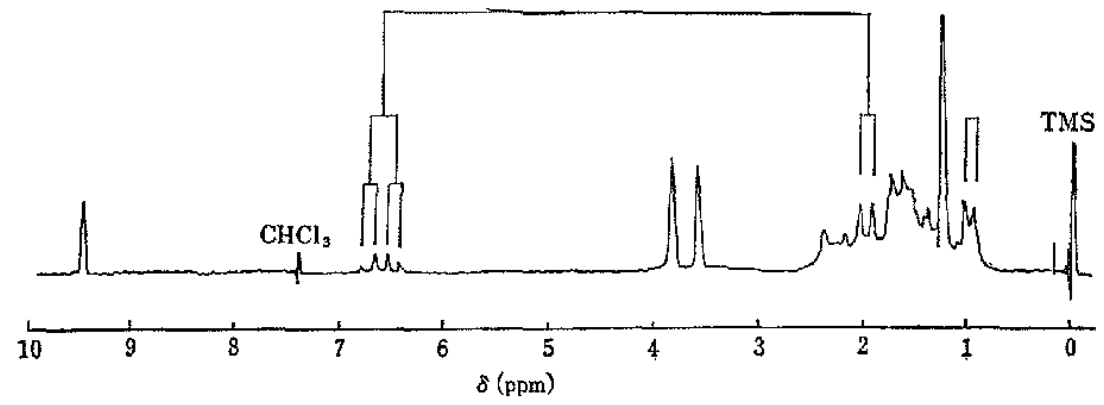

Fig. 6. NMR Spectrum of Carbonyl Compound (IV) at $60 \mathrm{Mc}$ in $\mathrm{CDCl}_{3}$ (TMS). 
(III)

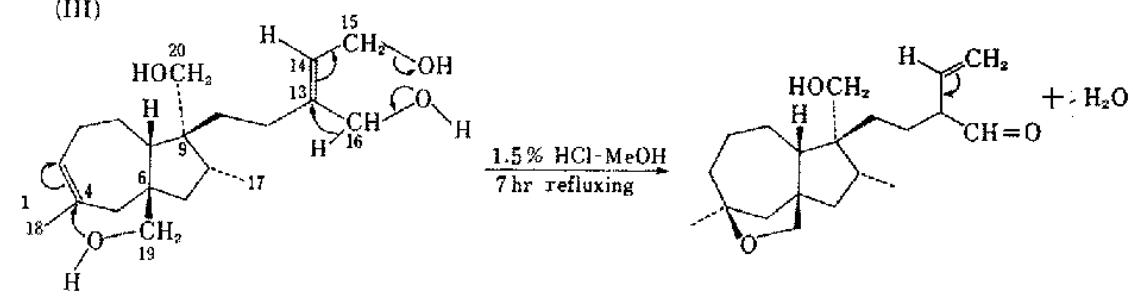<smiles>C/C=C\CC[C@@]1(C)[C@@H]2CCC[C@@]3(C)C[C@]2(CO3)C[C@H]1C</smiles>

Fig. 7. A Possible Mechanism for Transformation of (III) to Carbonyl Compound (IV).

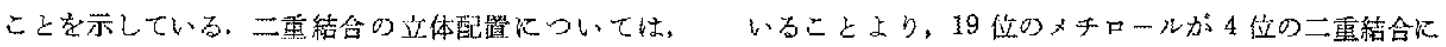

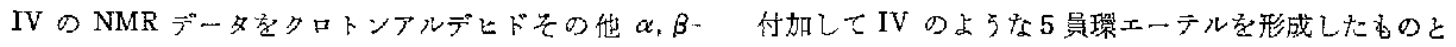

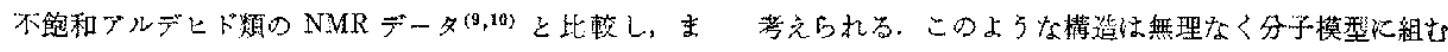

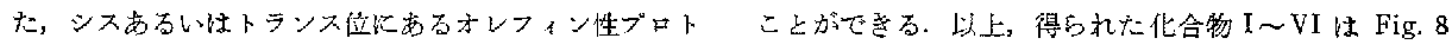

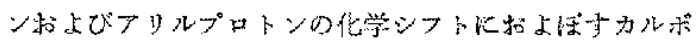

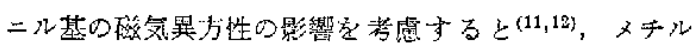

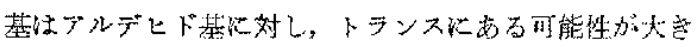

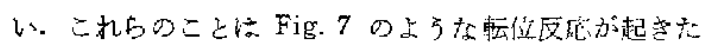
こと卖示晙している.

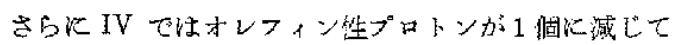

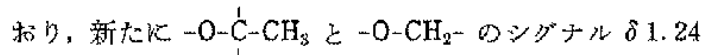
( $3 \mathrm{H}, 1$ 本線) 飞 $83.82(2 \mathrm{H}, 1$ 本線) 加走机艺机坐じて

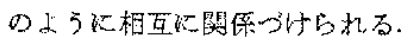

上速の上5に portulol 古るいは portulal の 2-but-

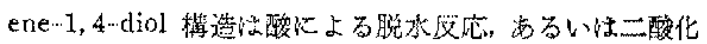
マンガンによる酸化のいずれの場合も， $\beta$-位に水素原

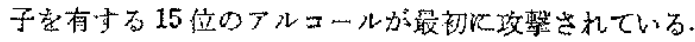
これはフリル共鳴によってカルポニウムイオンか安定化 しやすい構造比卡ると考光られる。

次に portulal 特上ひ portulol の生理活性について
(I)

(v) $\mathrm{C}_{26} \mathrm{H}_{36} \mathrm{O}_{7} \mathrm{~N}_{4} \stackrel{2,4-\mathrm{DNP}}{\longleftarrow}$<smiles>CC1=CCC[C@@H]2[C@@](C=O)(C1)C[C@@H](C)[C@@]2(CO)CC/C(=C/CO)CO</smiles>

(II)<smiles></smiles><smiles>CCC1=CCCC2C(C=O)(C1)CC(C)C2(C)CCC1=CC(=O)OC1</smiles>

(III)<smiles>CC1=CCC[C@H]2C[C@@](CO)(C/C(=C/CO)CO)[C@@H](C)[C@@]2(CO)C1</smiles><smiles>C/C=C/CC[C@]1(CO)[C@H](C)C[C@@]23COC(C)(CCC[C@H]21)C3</smiles>

(VI) $\mathrm{C}_{26} \mathrm{H}_{96} \mathrm{O}_{5} \mathrm{~N}_{4}$

Fig. 8. Correlation of Portulal Derivatives. 
<smiles>[R]/C(=C/CO)C(=O)O</smiles>

検討した. Table I, II にイネ・ラミナジョイントテス

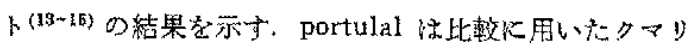

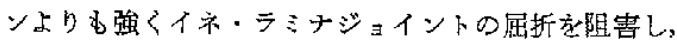
$50 \mathrm{ppm}$ で $80 \%$ の阻害が見られた。一万， portulol 多 弱いながら阻害活性が認められた.インドール酷酸を試

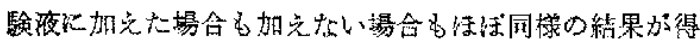
られた. 一方, ジヘレリン $\left(\mathrm{GA}_{3}\right)$ によ大考内肧乳の

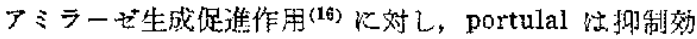
果を示したが, portulol 屺のような奻果を示さなるっ

Table I. Inhibitory Effect of Portulal on the Extention of Rice Lamina Joints

\begin{tabular}{|c|c|c|c|c|}
\hline \multicolumn{3}{|c|}{ Test soln. } & Angles & R.V. \\
\hline \multicolumn{3}{|c|}{ IAA $5 \mathrm{mg} /$ liter } & $95.8 \pm 3.2$ (p.e.) & $100 \%$ \\
\hline$" \prime$ & $+P-a 1$ & $50 \mathrm{mg} /$ liter & $18.7 \pm 1.2$ & 20 \\
\hline$n$ & + & 150 & $8.2 \pm 0.7$ & 9 \\
\hline$"$ & $+\mathrm{C}$ & 50 & $62.2 \pm 2.1$ & 65 \\
\hline$"$ & + & 150 & $29.4 \pm 1.5$ & 31 \\
\hline Water & & & $81.1 \pm 2.8$ & 85 \\
\hline$"$ & $+\mathbf{P}-\mathrm{al}$ & $50 \mathrm{mg} /$ liter & $15.1 \pm 1.4$ & 16 \\
\hline$"$ & + & 150 & $8.9 \pm 0.8$ & 9 \\
\hline " & $+\mathrm{C}$ & 50 & $51.5 \pm 2.4$ & 54 \\
\hline$"$ & + & 150 & $26.9 \pm 1.8$ & 28 \\
\hline
\end{tabular}

IAA ; indoleacetic acid. P-al; portulal. C ; coumarin. Angles; angles between laminae and sheaths in etiolated leaves. p.e.; probable error. $\mathrm{R}$, V.; relative values.

Table II. Inhibitory Effect of Portulol on the Extention of Rice Lamina Joints

\begin{tabular}{|c|c|c|c|c|}
\hline \multicolumn{3}{|c|}{ Test soln. } & \multirow{2}{*}{$\begin{array}{c}\text { Angles } \\
53.7 \pm 4.4(\text { p. e. })\end{array}$} & \multirow{2}{*}{$\frac{\text { R.V. }}{100 \%}$} \\
\hline IAA 5 & $5 \mathrm{mg} / \mathrm{liter}$ & & & \\
\hline & $\|+\mathrm{P}-\mathrm{ol}$ & $50 \mathrm{mg} /$ liter & $40.0 \pm 4.0$ & 74 \\
\hline & $"+$ & 150 & $36.7 \pm 3.3$ & 68 \\
\hline & $t+\mathrm{C}$ & 50 & $39.6 \pm 3.6$ & 74 \\
\hline & $y+$ & 150 & $20.4 \pm 1.2$ & 38 \\
\hline Water & & & $50.4 \pm 5.2$ & 94 \\
\hline & $" \prime+\mathrm{P}-\mathrm{ol}$ & $50 \mathrm{mg} /$ liter & $52.1 \pm 3.5$ & 97 \\
\hline & $\prime \prime+$ & 150 & $41.9 \pm 3.6$ & 78 \\
\hline & $11+\mathrm{C}$ & 50 & $30.4 \pm 2.3$ & 57 \\
\hline & $" 1+$ & 150 & $17.6 \pm 2.3$ & 33 \\
\hline
\end{tabular}

IAA ; indoleacetic acid. P ol ; portulol. $C$; coumarin. Angles; angles between laminae and sheaths in etiolated leaves. p.e.; probable error. R. V.; relative values.
Table III. Effect of Portulal and Portulol on the $\mathrm{GA}_{3}$-induced Formation of $\alpha$ amylase in Barley Endosperm

\begin{tabular}{cccc}
\hline GA & & & $\begin{array}{c}\text { Relative activities } \\
\text { of } \alpha \text {-amylase }\end{array}$ \\
+ Portulal & $9 \times 10^{-6} \mathrm{M}$ & & $100.0 \%$ \\
$+\quad "$ & $9 \times 10^{-8} \mathrm{M}$ & 78.0 \\
$+\quad "$ & $9 \times 10^{-8}$ & 68.3 \\
+ Portulol & $1.5 \times 10^{-5}$ & 26.8 \\
$\mathrm{GA}_{3} 0$ & & 102.7 \\
\hline
\end{tabular}

The concentration of reducing sugar produced was a measure of the amount of $a$-amylase formed.

$\mathrm{GA}_{\mathrm{g}}$; gibberellin $\mathrm{A}_{3}$

to (Table III).

最後に, portulol が植物体化存在するか否かを調查し たが、これを稳出するこにはできなかった、すなから，

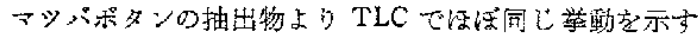

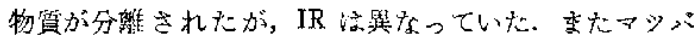
ボタンと同一属のスペりヒニ (Portulaca oleracea L.) の抽出物からイネのラミナジョイントテメトで阻䇺作䏛 を示卞るのが見出さ岵たが, portulal, portulol のいず れとも一致しながった。

$$
\text { 実 歌 }
$$

Melting pointは，特に部した場合を除いては徽量融

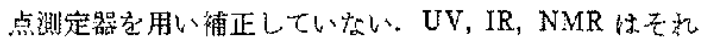
ぞれ Beckman DB-G 型分光光度棓，島汼 IR-27 G 分光

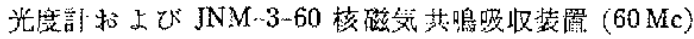
を用いて記録した。啠量分析法日本電子 JMS-01 SG 梨

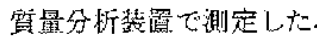

\section{Portulal (I) の単離と性诈}

マッメ亦タン (Portulaca grandiflora Hook.) の地上 部 $42.2 \mathrm{~kg}$ 細断し，メタノール50lに7 日間浸漬し

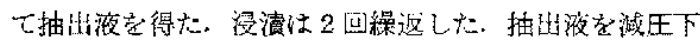

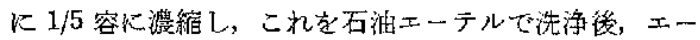

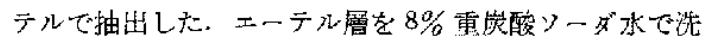
い，乾燥後減压濃縮してシリカゲル (Mallinckrodt 100 mesh) カラムクロマトグラフに方け，酷酸エチルで溶出 して 5.5 g の粗結晶を得た。再度シりクゲルカラムに付

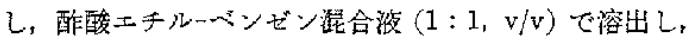

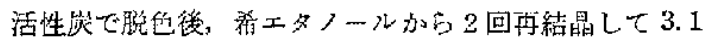
g D無色針状晶を得た。 $m p 117.0 \sim 117.5^{\circ} \mathrm{C}$ (補正值), $[\alpha]_{\mathrm{D}}^{12}-61.1^{\circ}(c=2.62, \mathrm{EtOH})$, 分析値: C 71.39, H 
$9.70 \%, \mathrm{C}_{20} \mathrm{H}_{32} \mathrm{O}_{4}$ の計算值 : C $71.39, \mathrm{H} 9.59 \%, \mathrm{R}$ $\nu_{\max }^{\mathrm{KBr}} \mathrm{cm}^{-1}: 3260(\mathrm{~b}, \mathrm{OH}), 2910,2719(-\mathrm{CO}-\mathrm{H}), 1722$ $(\mathrm{C}=0), 1708(\mathrm{C}=\mathrm{O}), 1460,1446,1384,1366,1245$, $1026\left(\mathrm{CH}_{2} \mathrm{OH}\right), 857,835$ (三置搰オレフィン). NMR

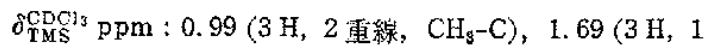
本線, $\left.\mathrm{CH}_{3}-\mathrm{C}=\right), 3.64\left(2 \mathrm{H}, 1\right.$ 本線, $\left.-\mathrm{CH}_{2} \mathrm{OH}\right), 4.17(2$ $\mathrm{H}, 2$ 重楾, $\left.J=6.3 \mathrm{cps},=\mathrm{C}<\mathrm{CH}_{2}^{\mathrm{H}} \mathrm{OH}\right), 4.18(2 \mathrm{H}, 1$ 本

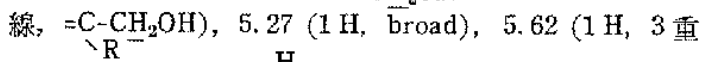
線, $\left.J=6.3 \mathrm{cps}_{1}=\mathrm{C}<\frac{\mathrm{H}}{\mathrm{CH}_{2} \mathrm{OH}}\right), 9.52(1 \mathrm{H}, 1$ 本線, $-\mathrm{CHO})$. UV $\lambda_{\max }^{\text {EtOH }} \mathrm{m} \mu(\varepsilon): 282(80)$.

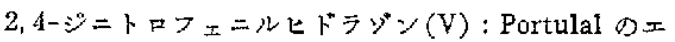
タノール溶液に2,4-ジニトロフェニルとドラジンの硫 酸エタノール液学加之常法 ${ }^{(17)}$ により得た。黄色針状晶， $\mathrm{mp} 115 \sim 118^{\circ} \mathrm{C}$, 分析值: C $60.20, \mathrm{H} 7.09, \mathrm{~N} 10.72$ $\% . \mathrm{C}_{26} \mathrm{H}_{38} \mathrm{O}_{7} \mathrm{~N}_{4}$ の計賞值: C 60.45, H 7.02, N $10.85 \%$. IR. $\nu_{\mathrm{max}}^{\mathrm{CHCl}} \mathrm{cm}^{-1}: 3624(\mathrm{OH}), 3324(\mathrm{NH}), 1620(\mathrm{C}=\mathrm{N})$, 1590 (NO), 1515 (broad, ベンゼン核), 1339 (NO). NMR $\delta_{\mathrm{T} S \mathrm{~S}}^{\mathrm{CDCl}_{3}} \mathrm{ppm}: 1.02\left(3 \mathrm{H}, 1\right.$ 本線, $\left.\mathrm{CH}_{\mathrm{s}}\right), 3.74(2$ $\mathrm{H}, 1$ 本線, $\left.-\mathrm{CH}_{2} \mathrm{OH}\right), 4.28\left(4 \mathrm{H}, \mathrm{I}\right.$ 本線, $=\mathrm{C}-\mathrm{CH}_{2} \mathrm{OH} \times$ 2), $7.71(1 \mathrm{H}, 1$ 本線, $-\mathrm{CH}-\mathrm{N}-), 8.06(1 \mathrm{H}, 2$ 荲線, $J=9.6 \mathrm{cps}$ ), 8.50 ( $1 \mathrm{H}, 4$ 重線, $J=9.6 \mathrm{cps}, 3 \mathrm{cps}$ ), $9.33(1 \mathrm{H}, 4$ 重線, $J=3 \mathrm{cps}), 11.22(1 \mathrm{H}, 1$ 本線, $=\mathrm{N}-$ $\mathrm{H})$, UV $\lambda_{\mathrm{m \varepsilon \pi}}^{\mathrm{EtOH}} \mathrm{m} \mu(\varepsilon): 363(21,200)$.

\section{Portulal の活性二㱥化マンガンにる酸化 ${ }^{(6)}$}

Portulal の $508 \mathrm{mg}$ 学クロロホルム $25 \mathrm{ml}$ に溶汃し， 活性二酸化マンガン2.81g 加学, 室温比一眖放置し た。源液を減王淟縮して淡黄色油状物質を得た。これを シリカダル薄㬝クロマトに付 $2, \mathrm{CHCl}_{3}$ : AcOEt (10: $1, \mathrm{v} / \mathrm{v})$ て展開し, 原点に留った部分を丽度 $\mathrm{CHCl}_{3}$ : AcOEt (8:1, v/v) を用いて薄層クロマトグラフを行な

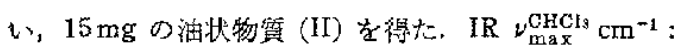
$3645\left(-\mathrm{CH}_{2} \mathrm{OH}\right), 3475,2930,2713(-\mathrm{CHO}), 1787,1749$ ( $\gamma$-ラタトン), 1729 (-CHO), $1642(\mathrm{C}=\mathrm{C}), 1452,1235$, $1037\left(-\mathrm{CH}_{2} \mathrm{OH}\right), 895,857$. IR $\nu_{\mathrm{rn} \theta \mathrm{x}}^{\mathrm{CCl}_{4}} \mathrm{~cm}^{-1}: 2940,2700$ (-CHO), 1786, 1756 ( $\gamma-$ ラタトン), 1729 (-CHO), 1640 $(\mathrm{C}=\mathrm{C})$.

\section{Portulal の LiAlH 4 姏理による Portulol (III) の生} 成

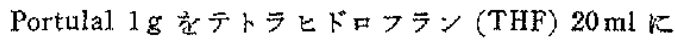
溶加し， $\mathrm{LiAlH}_{4}$ の THF 溶液 $(175 \mathrm{mg} / 27 \mathrm{ml})$ を少しず

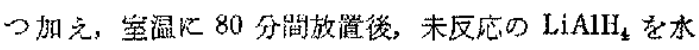
で分解した.ついで反応混含液を $10 \% \mathrm{H}_{2} \mathrm{SO}_{4}$ で処理
し、エーテルで抽出した、エ一テル抽出液を水洗, 乾罗 㷋淢王下に浴媒を留去し，残盗をシリカゲルTLC 沉 讨AcOEt て展開，精製して，吸澄性の無色粉末 $812 \mathrm{mg}$

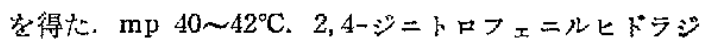
ン試騟, 陰性. S分析值: C 70.15, H $10.05 \% . \mathrm{C}_{28} \mathrm{H}_{34} \mathrm{O}_{4}$ の計算犆: C 70.97, H 10.13\%. IR $\nu_{\max }^{\mathrm{KBr}} \mathrm{cm}^{-1}: 3325$ (OH, broad), 2900, 1452, 1384, 1250, $1122\left(-\mathrm{CH}_{2} \mathrm{OH}\right)$,

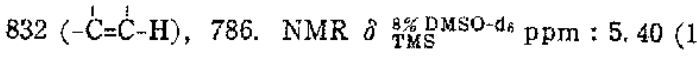
$\mathrm{H}, 3$ 重線, $J=6.9 \mathrm{cps}, \mathrm{H}-\mathrm{C}=\mathrm{C}), 5.30(1 \mathrm{H}$, broad, H$\mathrm{C}=\mathrm{C}$ ), $4.07\left(2 \mathrm{H}, 2\right.$ 箽線, $J=6.9 \mathrm{cps},=\mathrm{C}-\mathrm{CH}_{2} \mathrm{OH}$ ), $3.94\left(2 \mathrm{H}, 1\right.$ 本線, $\left.=\mathrm{C}-\mathrm{CH}_{2} \mathrm{OH}\right), 3.44\left(2 \mathrm{H},-\mathrm{C}-\mathrm{CH}_{2} \mathrm{OH}\right)$, $3.30\left(2 \mathrm{H}, \mathrm{C}-\mathrm{CH}_{2} \mathrm{OH}\right), 1.66\left(3 \mathrm{H}, 1\right.$ 本線, $\left.\mathrm{CH}_{3}-\mathrm{C}=\mathrm{C}\right)$, $0.94\left(3 \mathrm{H}, 2\right.$ 重線, $\left.J=5.4 \mathrm{cps}, \mathrm{C}-\mathrm{CH}_{3}\right)$. MS m/e : 338 $\left(\mathrm{M}^{+}\right), 320\left(\mathrm{M}^{+}-\mathrm{H}_{2} \mathrm{O}\right), 307\left(\mathrm{M}^{+}-\mathrm{CH}_{2} \mathrm{OH}\right)$.

\section{Portulol の酸赺理によるカルボニル化合物 (IV) の生} 成

Portulol $124 \mathrm{mg}$ をメターール $2 \mathrm{ml}$ に溶かし， 1.5\%

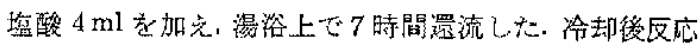

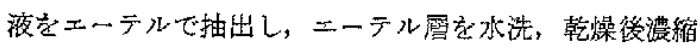
して，淡黄色国体を得な。これをシリカゲルTLCにか if $\mathrm{CHCl}_{\mathrm{s}}: \operatorname{AcOEt}(1: 1, \mathrm{v} / \mathrm{v})$ で展開，精製後ニーテル 加方再結晶して舞色立方晶 $40 \mathrm{mg}$ 得た。 mp 113〜 $114^{\circ} \mathrm{C}$. 分析值 : C $74.31, \mathrm{H} .99 \% . \mathrm{C}_{20} \mathrm{H}_{32} \mathrm{O}_{3}$ の計算 值: C 74.96, H 10.06\%. IR $\nu_{\max }^{\mathrm{CHCl} \mathrm{cm}^{-1}}: 3645(\mathrm{OH})$, $3460,2925,2860,2720$ (-CHO), 1679 ( $\mathrm{C}=\mathrm{C}-\mathrm{CHO})$,

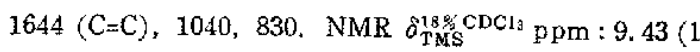
$\mathrm{H}, 1$ 本線, $-\mathrm{CHO}), 6.60(1 \mathrm{H}, 4$ 重線， $J=7.1 \mathrm{cps，}$ $\mathrm{H}-\mathrm{C}=), 3.82\left(2 \mathrm{H}, 1\right.$ 本線, $\left.-\mathrm{CH}_{2} \mathrm{OH}\right), 3.57(2 \mathrm{H}, 1$ 本 線, $\left.\mathrm{C}-\mathrm{CH}_{2}-\mathrm{O}-\mathrm{C}\right), 1.97\left(3 \mathrm{H}, 2\right.$ 重線, $J=7.1 \mathrm{cps}, \mathrm{CH}_{\mathrm{s}}-$ $\mathrm{C}=), 1.24\left(3 \mathrm{H}, 1\right.$ 本線, $\left.\mathrm{CH}_{\mathrm{g}}-\mathrm{C}-\mathrm{O}\right), 0.98(3 \mathrm{H}, 2$ 重線, $\left.f=5.7 \mathrm{cps}, \quad \mathrm{CH}_{3}-\mathrm{C}\right)$. UV $\lambda_{\max }^{\mathrm{EtOH}} \mathrm{m} \mu(\varepsilon): 273(3900)$, $230(30,500)$. MS m/e : $320\left(\mathrm{M}^{+}\right), 302\left(\mathrm{M}^{+}-\mathrm{H}_{2} \mathrm{O}\right), 289$ $\left(\mathrm{M}^{+}-\mathrm{CH}_{2} \mathrm{OH}\right)$.

2,4-ジニトロフニニルとドラゾン (VI): 黄褐芭結晶, $\operatorname{mp~} 227 \sim 229^{\circ} \mathrm{C}$. 分析値: C 57.93, H 6.76, N 10.00 $\% . \mathrm{C}_{26} \mathrm{H}_{36} \mathrm{O}_{6} \mathrm{~N}_{4}$ の計算値 : C $62.38, \mathrm{H} 7.25, \mathrm{~N} 11.19$

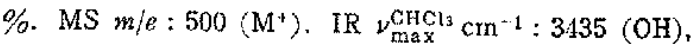
$3300,2925,2850,1618(\mathrm{C}=\mathrm{N}), 1593(\mathrm{~N}=0), 1511$ ( ^ ンゼン核), $1336(\mathrm{NO}), 832(-\mathrm{C}=\mathrm{C}-\mathrm{H})$. UV $\lambda_{\max }^{\mathrm{CHCls}} \mathrm{m}_{4}$ (ع) : $258(14,000), 378(22,000)$.

\section{经潖性の測定}

ラミナジョイントテスト:テスト法は前田らの報告(19 
15)に準して行なった．播稹後，7〜9日目の水稻（農林18）

号) 纤苗を使用した．蒸留水で前処理することなく，南

接, 試験液に葉切片を浮べた、試験液にはインドール酷

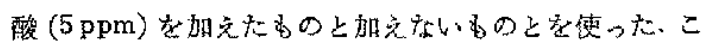

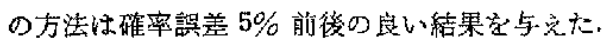

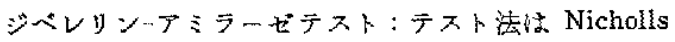

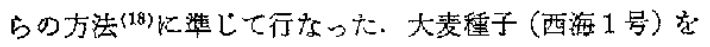

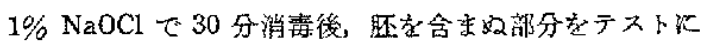

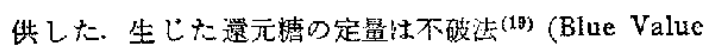
測定法) K良った。

\section{要約}

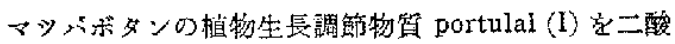
化マンガンで酸化するとケーラクトン (II) を生じまた

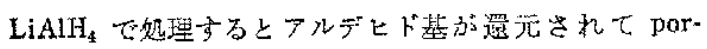

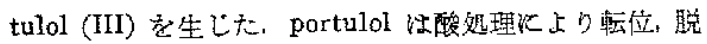

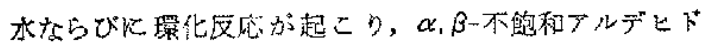
(IV) に変化した. I, III は共以イホ・ラミナジョイント

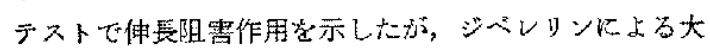
麦のアミラーゼ生成効果汇対して柱Ｉのみが阻憲作用を 西した。

終りに，同定のため貴重な portulal の武料とスペク トルデータとを御提供いただいた東京大学㤟学部田村三

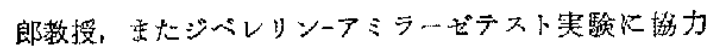
された九州大学费学部田中侓治民に感謝いたします。

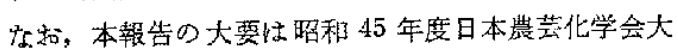
会（福岡）に就いて発丧した。

(1) M. Mitsuhashi and H. Shibaoka : Plant and Cell Physiol., 6, 87 (1965).
(2) M. Mitsuhashi, H. Shibaoka and M. Shimokoriyama : Plant and Cell Physiol, 10, 715 (1969).

(3) S. Yamazaki, S. Tamura, F. Marumo and Y. Saito: Tetrahedron Letters, 1969, 359.

(4) 田村三郎: 私俑 (1970).

(5) R. N. Jones, C. L. Angell, T. Ito and R. J. D. Smith: Can. J. Chem., 37, 2007 (1959),

(6) J. Attenburrow, A. F. B. Cameron, I. H. Chapman, R. H. Evans, B. A. Hems, A. B. A. Jansen and T. Walker: J. Chem. Soc., $1952,1104$.

(7) N. W. Atwater:J. Am. Chem. Soc., 83, 3071 (1961).

(8) L. A. Jones, J. C. Holmes and R. B. Seligman: Anal. Chem., 28, 191 (1956).

(9) N.S. Bhacca, D.P. Hollis, L. F. Johnson and E. A. Pier: NMR Spectra Catalog I, II, Varian associate, 1963.

(10) L. M. Jackman and R. H. Wiley : $J$. Chem. Soc., 1960, 2881.

(11) L. M. Jackman, "Application of Nuclear Magnetic Resonance Spectroscopy in $\mathrm{Or}$ ganic Chemistry," Pergamon Press, London, 1959, p. 119 .

(12) M. D. Nair and Roger Adams : J. Am. Chem. Soc., 83, 922 (1961).

（13）前男英三：雑草研觉，2，113 (1963).

（14）前田英三，河标嗮司：日作紀，31，61 (1962).

(15) 前田英三：植物生理，4，118(1964).

(16) J. E. Varner : Plant Physiol., 39, 413 (1964).

(17) R. L. Shriner, R. C. Fuson and D. Y. Curtin, "The Systematic Identification of Organic Compounds," Maruzen Co., Tokyo, 1956, p. 219.

(18) P. B. Nicholls and L. G. Paleg: Nature, 199 , 823 (1963).

(19) H. Fuwa : J. Biochem., 41, 583 (1954). 